\title{
Can Asian Countries Live Together in Peace and Harmony?
}

"If the US would only leave Asia, we Asians could all live together in peace and harmony," a group of over 40 Chinese students said in response to my question. But when I reported this exchange back to another one of my classes, the Americans in the group instantly retorted that "Asia would descend into war if ever the US left Asia to itself-Asians hate each other."

I was shocked at both the sharpness of the two reactions and the unanimity of the feelings of each of the two groups of students. So I invited a Chinese professorial colleague to lunch to see her reactions. She almost jumped in responding: "Why must the US have a system of alliances with so many Asian countries surrounding China? The US is not an Asian country. The US is just encircling China, trying to hem us in. It is trying to stop China's rise. It sees China's rise as a threat. The US just wants to remain Asia's hegemon."

These revealing comments highlight the great power transition under way in Asia-from a US-led region to perhaps a China-led one. Asia's post-World War 2 geopolitics are being shaken by the rise of China, and China is now engaged in a bitter power struggle with the US and its Asian allies for the political leadership of Asia. At this stage, the US seems to be losing its hold over Asia, something which will likely accelerate under the Trump administration. China has signed up most Asian countries to its new initiatives like the Asian Infrastructure Investment Bank (AIIB) and the Belt and Road Initiative (BRI), which the US and Japan have boycotted. China is also proving very effective at subjugating many 
of its neighbors through its market, financial and military power. For its part, the US is distracted by the Middle East, Russia and the circus of Washington, and has difficulties being consistent from one administration to another.

China's burgeoning domination of Asia is incongruous in many ways. When compared with Japan, Korea, Taiwan, Hong Kong and Singapore, China's economy is inferior in terms of GDP per capita, and economic, business and technological sophistication. Its citizens suffer from human rights abuses, widespread restrictions on freedom, censorship of information and dubious official propaganda. And its government is neither democratic nor transparent, and is shrouded in secrecy and is accountable to no one but itself.

But China does have size on its side thanks to its enormous population. This means that it has the world's biggest economy in purchasing power parity terms, the largest foreign exchange reserves and the highest military expenditure in Asia. China is also the most important trading partner of virtually all other Asian economies. And it is not shy to assert its political and military power, even it means breaking international law to which it has signed up.

The Chinese are also motivated by an enormous belief in their destiny. As former US Secretary of State, Henry Kissinger, once said, "The Chinese think of themselves as having always been on top and that there was only an interruption of a hundred years in which the West exploited its momentary weakness. And in their mind, they are reclaiming their traditional position." In short, China has great economic weight and motivation, which it has transformed into economic, political and military power.

No one can be sure how the future will unfold and what the "new normal" will be. Traditional military conflict cannot be ruled out, though perhaps not between China and the US. American business is hooked on the Chinese market, and US diplomatic and military leaders would not want to put this at risk. The US also needs Chinese cooperation on issues like North Korea, counter-terrorism, cyber-security, Iran and, depending on the administration, climate change. And both sides seem very conscious of the futility and massive costs of a possible military conflict.

But despite the size of its market and military, China has very few friends in Asia, and the potential is enormous for conflict with Japan, Taiwan, Hong Kong, Vietnam and especially India. And China has been the ultimate guarantor of North Korea, Asia's greatest security risk. 
The relative peace that Asia has enjoyed these past seven decades has been key to the region's economic renaissance. But as we discuss in this chapter, a peaceful future in Asia cannot be taken for granted. Indeed, the ability of Asians to live together in peace and harmony will perhaps be the most important determinant of a successful Asian Century.

How did we get into this situation? What are Asia's hot spots? And what will the future hold?

\section{US and Asia During the Cold War}

The Chinese communist government's giant military parade on Tiananmen Square on 3 September 2015 to celebrate the 70th anniversary of the "Victory of the Chinese People's War of Resistance Against Japanese Aggression" was a grotesque affair with perfectly goose-stepping soldiers and a massive display of new military equipment, including the DF-21D, the so-called carrier killer anti-ship ballistic missile. It was also a sham. The US, along with China's nationalist army (the Kuomintang-KMT), was responsible for bringing an end to Japan's aggression and to the Pacific side of World War 2-the Communist Party had virtually nothing to do with it.

In fact, China's communists were fortunate that the KMT had invested so much energy in fighting the Japanese that they could then easily beat the diminished KMT in the subsequent Chinese Civil War, which ended in 1949. Another major event that shaped Cold War relations in East Asia was the Korean War which saw the peninsula divided between North Korea, supported by China and the USSR, and South Korea, supported by the US and its allies, from war's end in 1953.

As the ultimate victor of World War 2, the US faced a complex postwar geopolitical landscape. Asia's only great power, Japan, was not only defeated, it was virtually destroyed. The process of decolonization in Asia was beginning, leaving many new nations to fend for themselves. This period also witnessed the onset of the Cold War with countries like Japan, South Korea, the Philippines, Taiwan and Thailand lining up on the American side, and China, North Korea and the USSR on the other side. Reflecting these Cold War politics, Taiwan occupied China's seat at the United Nations (UN), the IMF, World Bank and other international organizations, with the People's Republic being virtually sidelined. 
The US government was very keen to provide its allies with security. But the US did not want to give them a blank check to start wars and entrap it in parochial conflicts. The US needed to control these allies. So the US created a bilateral "hub-and-spoke" alliance system in Asia, which provided its Asian allies with security, but kept them under control. Quite deliberately, it did not create an "Asian NATO", because the US did not have sufficient trust in its Asian allies. For their part, these Asian countries did not have any need for an Asian NATO once the US had provided them with sufficient security through tight bilateral agreements. In the case of Japan, at the time Asia's most important country, the US occupying powers went further, and virtually created a new nation, a democracy, with a constitution that renounced to right to wage war. ${ }^{2}$

The alliances with Japan, South Korea, the Philippines and Thailand remain in place to this very day (the US also has a close military partnership with Singapore). In 1979, the US switched its allegiances and recognized mainland China as "one China" rather than Taiwan. But the US did not totally abandon Taiwan. It implemented new security obligations through the US Taiwan Relations Act which states that "the United States will make available to Taiwan such defense articles and defense services in such quantity as may be necessary to enable Taiwan to maintain a sufficient self-defense capabilities." This legislation is designed to deter both China from invading Taiwan and Taiwan from unilaterally declaring independence.

As the US system of alliances provided security to its Asian friends, it also underpinned the exceptional economic development that these countries would experience. But the US provided even greater support to its Asian friends. In the immediate post-war years, they received financial assistance to help reconstruct their economies. They benefited from the stability and open markets fostered by the new multilateral economic system, including most notably the UN, IMF, World Bank and the GATT (which would become the World Trade Organisation). The export-driven development of Japan, Hong Kong, Korea, Singapore and Taiwan would also benefit greatly from the substantial openness of US markets to exports from these countries. It is important to stress that as generous as the American actions might seem, they were substantially motivated by geopolitics. After years of World War 2, and with the emerging Cold War, the US had as much interest in promoting peace, stability and security as anyone. $^{3}$ 
Perhaps one of the most important developments in the post-war period was that, despite the violent war, Japan was able to reestablish peaceful and friendly relations with most of its former adversaries. For example, on the 70th anniversary of the end of World War 2, on 2 September 2015, US President Barack Obama said:

"The end of the war marked the beginning of a new era in America's relationship with Japan. As Prime Minister Abe and I noted during his visit in April, the relationship between our two countries over the last 70 years stands as a model of the power of reconciliation: former adversaries who have become steadfast allies and who work together to advance common interests and universal values in Asia and globally. Seventy years ago this partnership was unimaginable. Today it is a fitting reflection of our shared interests, capabilities, and values, and I am confident that it will continue to deepen in the decades to come." Japanese Prime Minister Shinzo Abe's visit to Pearl Harbour in late 2016 was also emblematic of the reconciliation and friendship between the US and Japan. It may also have been motivated by Abe's fear that President Trump will downplay the US-Japan Alliance.

In a similar spirit, Australia's former Prime Minister Tony Abbott told Japan's Shinzo Abe, when these two prime ministers met at an East Asia Summit in Brunei in 2013. "As far as I'm concerned, Japan is Australia's best friend in Asia and we want to keep it a very strong friendship." There are now only a few Asian nations with which Japan now has poor relations, notably China, North Korea and South Korea. Efforts by the US to prod Japan and South Korea to bury the hatchet, notably over Japan's forced employment of Korean "comfort women", are still struggling to achieve durable results.

On a visit to Japan in 2015, Germany's Chancellor Angela Merkel had some wise advice on post-war reconciliation when she spoke of Germany's readiness "to face our history openly and squarely", but also of the "generous gestures of our neighbours". In other words, post-war reconciliation requires efforts on both sides. And regrettably, anti-Japanese sentiment is a still an important tool in domestic politics in China, and North and South Korea.

Overall, the US played a major role in fostering the rapid and peaceful development of its allies and friends in the post-war period, including the successful democratization of Korea and Taiwan. The US would also make a major contribution to China's development, when it finally opened up its economy. 


\section{ReHabilitation of China}

Although China was substantially isolated from the West and the rest of Asia, over the years from 1949, the People's Republic of China worked hard to secure international recognition and support for its position that it, not Taiwan, was the sole legitimate government of all China, including Hong Kong, Macau and Taiwan. Thus, a growing number of Western countries recognized the People's Republic of China, starting with Switzerland, Sweden, Denmark and Finland in 1950. Other important milestones along the way included recognition by Canada (1970), UK (1972), Japan (1972) and Australia (1972). A major turning point occurred when Taiwan, which had occupied China's seat at the UN since 1945, was effectively expelled on 25 October 1971, with its seat being taken over by the People's Republic of China. Indeed, the People's Republic took over the China seat in all international organizations.

But the most important event in the rehabilitation of the People's Republic was the visit to China in 1972 by US President Richard Nixon and National Security Advisor Henry Kissinger, and the subsequent, in 1979, formal recognition of the People's Republic by the US, and its severing of relations with Taiwan. At China's insistence, the US also adhered to the "One-China Policy" by which there is only one China, and Taiwan is considered a renegade province which must in time be reunited with the motherland.

While the US was keen to join forces with China against the USSR in the Cold War of the day, it was also motivated by Nixon's belief that China should be brought into the international system. In 1967 Nixon wrote "Taking the long view, we simply cannot afford to leave China forever outside the family of nations, there to nurture its fantasies, cherish its hates and threaten its neighbours... There is no place on this small planet for a billion of its potentially most able people to live in angry isolation." In more recent years, US President Obama emphasized that his administration welcomes China's peaceful rise, and believes that a strong and prosperous China is one that can help to bring prosperity and stability to the region and the world.

From the moment of US recognition of People's Republic of China, through various administrations, US policy was always designed to support the revival of the Chinese economy, even if there have been ups and downs, like the Tiananmen Square Massacre. Another major step took place in 2000, when President Bill Clinton signed into law the U.S.-China 
Relations Act which granted permanent normal trade relations to China, against stiff opposition from labor and human rights groups. This facilitated China's entry into the World Trade Organization in 2001. Prior to passage of the bill, China was subject to an annual review of its trade status with the US.

There were of course powerful US business interests supporting the normalization of trade relations between the US and China. But President Clinton believed that there were also powerful political interests when he said: “...many of [China's leaders] believe that we honestly don't want their country to assume a respected place in the world. If ... we turn our backs on them, it will confirm their fears." He also said: "Membership in the WTO, of course, will not create a free society in China overnight or guarantee that China will play by global rules. But over time, I believe it will move China faster and further in the right direction, and certainly will do that more than rejection would."

While China's dramatic economic transformation since 1978 owes a great deal to the reforms initiated by Deng Xiaoping, China has benefited greatly from the openness of the US economy, which is vastly more open than the Chinese economy. Today, China is the US' largest supplier of merchandise imports and the third largest market for US merchandise exports. US goods and services trade with China totaled an estimated $\$ 659.4$ billion in 2015 , with the US having a goods and services trade deficit with China of $\$ 336.2$ billion in $2015 .^{8}$

The US is becoming a very important destination for China's outbound investment, with Chinese companies investing a record $\$ 45.6$ billion of foreign direct investment (FDI) in 2016. This threefold increase from 2015 is helping Chinese companies acquire technology, knowhow and brands, and penetrate US markets. It is estimated that the US has received over $\$ 100$ billion in FDI from China since the year 2000. ${ }^{9}$ Since Chinese outbound investment is a relatively new phenomenon, the stock of US investment in China is very much higher.

Another point of point of access to US knowledge is through the 330,000 Chinese students studying in the US in 2016, accounting for over $30 \%$ of the US' international students. China has also become a massive source of tourist revenues for the US. In 2016, 3 million Chinese tourists visited the US, and with $\$ 33$ billion in visitor spending, they were by far the US' most important source of tourist dollars. And according to the 2010 census, there are some 3.8 millions of Americans of Chinese descent, reflecting the openness of America's society. 
In sum, the US has contributed greatly to the development of the Chinese economy. But as China's rise has progressed, the US economy has become increasingly dependent on China, which has reduced US' political leverage over China.

As we discussed in Chap. 4, trade and investment with Japan has been another factor driving the Chinese economy forward. But friendly relations between these countries took a turn for the worse after the Tiananmen Square massacre, thereby destabilizing the foundations for peace and harmony in Asia.

\section{Japan, from Chinese Friend to Foe}

Japan has been the subject of growing Chinese vitriol these past few years. The dispute over the contested Senkaku/Diaoyu Islands has only increased. Despite Japan's manifold apologies for its atrocious war crimes in World War 2, China keeps questioning Japan's sincerity, and requests more and more apologies. The Chinese government seeks every opportunity it can to humiliate Japan.

At the same time, the actions of the Japanese government have not helped. Visits by Japanese Prime Minister Shinzo Abe and other leading government figures to the Yasukuni Shrine which honors among others Japanese war criminals have incensed not only China but also Korea. Comments by right wing Japanese political figures which question the veracity of events like the Nanjing Massacre and other Japanese wartime violence only add fuel to the fire. But what is also clear is that the Chinese government is actively promoting anti-Japanese sentiment, especially through grotesque television dramas. And as China regularly whips itself up into a frenzy over Japan, it is perhaps easy to forget that China's modern anti-Japanese sentiment is only a recent phenomenon.

During the 1970s and 1980s, China and Japan actually had good relations. In 1972, Mao Zedong told Prime Minister Kakuei Tanaka that his apologies for Japan's wartime aggression were not necessary, and expressed gratitude for Japan's help in defeating Chiang Kai-shek's KMT national army. Also in 1972, in a joint communiqué signed by Premier Zhou Enlai, China magnanimously renounced its right to war reparations, satisfying itself with Japan's acceptance of "responsibility for serious damage caused to the Chinese people through war." And following Deng Xiaoping's historic visit to Japan in 1978, relations between the two countries improved greatly. Japan played a key role in the take-off of the backward Chinese 
economy through financial assistance, corporate investments and technology transfer.

But things changed quickly after the 1989 Tiananmen Square Massacre, even though Japan was the first country to restore high-level relations with China following the diplomatic rupture with advanced countries. One lesson that the Chinese leadership drew from the Tiananmen Square incident was that the Communist Party needed to make greater efforts to promote nationalism to improve support for the Party. So under the leadership of Jiang Zemin, China embarked on a massive campaign of patriotic education. Students and citizens were taught how the Communist Party was leading China's recovery from its "century of humiliation" (from the opium wars to the end of the civil war in 1949). And at the heart of this patriotic education was anti-Japanese propaganda, since Japan was the country that inflicted the most suffering on China. As academic Minxin Pei has argued, the official anti-Japanese campaign has left deep scars: "Chinese state media and history textbooks have fed the younger generation such a diet of distorted, jingoistic facts, outright lies, and nationalistic myths that it is easy to provoke anti-Western or antiJapanese sentiments." 10

There have been other factors that have weakened China's burgeoning friendship with Japan. With the end of the Cold War and the dissolution of the USSR, China and Japan lost a common enemy which had helped unite them. And with its rapid development, China increasingly believed that it had less need for Japanese aid, investment and technology.

Is there any hope that China and Japan could bury the hatchet and have friendly relations?

It is very difficult to see a positive way out in the immediate future, even though it is ultimately in the interests of both countries to have good relations. The Chinese government has invested so much political energy in its anti-Japan propaganda that it would be difficult for it to back down. With its shaky economy and obvious political fragility, we are likely to see more, not less, Chinese nationalism. And China's anti-Japan propaganda has also emboldened Japan's right wing, which seeks to minimize Japanese wartime atrocities. It is also fostering "apology fatigue", especially among Japanese citizens born after the war.

Over the past couple of years, there has been a little softening of the rhetoric between the two countries. They regret the unfortunate economic costs of the "war of words", especially as Japanese investment in China has fallen dramatically over the past few years. Both leaders have 
met at international events. But it will likely require generational change in both countries, and probably democracy and freedom of the press in China, for real reconciliation to ever take place between the two countries.

As reconciliation will take a very long time, Asian neighbors and indeed the whole world must stay prepared for Northeast Asia remaining one of the world's political hotspots. Indeed, as Japan's Akiko Fukushima has argued, the security environment in Northeast Asia has seriously worsened over past decade with China's military buildup, the thickening of its presence in the South and East China Seas and North Korea's missile testing. This was the motivation for Japan's new security strategy, released in 2013, by which it has shifted from a passive and reactive approach to a proactive one. ${ }^{11}$

Like Japan, Taiwan is another country which, through its trade and investment, has made a major contribution to China's development. But since the election in 2016 of Tsai Ing-wen of the pro-independence Democratic Progressive Party (DPP) to presidency of Taiwan, the Taiwan Straits have become another one of Asia's hotspots.

\section{TaIWAn And China: IT's Complicated}

China still regards Taiwan as a renegade province, which must be reunified with the mainland under the banner of its "one-China policy", even though it is almost seven decades since Chiang Kai-shek's Chinese Nationalist Party (KMT) fled to Taiwan after losing the China's Civil War in 1949. Today, China's claims seem anachronistic, as Taiwan's GDP per capita is more than three times that of the mainland, and Taiwan has been a successful democracy since the early 1990s in sharp contrast to the increasingly authoritarian China. But China's claims to Taiwan are only intensifying in tandem with its growing economic power. The growing impatience of Chinese President Xi Jinping was palpable when he said that the "Taiwan issue cannot be passed on from generation to generation."

Taiwan is one of Asia's most democratic countries. Its citizens have a choice between two major political parties with different policy agendas. The KMT supports Beijing's one-China policy, and has had very good working relations with Beijing. The DPP is a pro-independence party which Beijing detests. In recent years, there has also been a real and meaningful alternance of power between these two parties, in contrast to Japan which has been dominated by the Liberal Democratic Party. Chen 
Shui-bian of the DPP was Taiwan's President from 2000 to 2008, and was followed by Ma Ying-jeou of the KMT from 2000 to 2016. And then following widespread dissatisfaction with the KMT, Madame Tsai Ing-wen of the DPP was elected president, the first female head of state or government in a Chinese territory.

Why would Taiwanese citizens elect the DPP's Madame Tsai and risk the wrath of China's assertive leaders?

The return of the KMT to the presidency in 2008 under Ma Ying-jeou ushered in a golden age of relations between Taiwan and China. Official contacts with Beijing, which had been on hold since 1999, were revived. A free trade agreement between China and Taiwan was signed in 2010. Tourists from Mainland China were permitted to visit Taiwan starting in 2008, with more than ten million Chinese tourists traveling to Taiwan since that time. Overall, more than 20 economic, academic and cultural agreements were signed between Taipei and Beijing under Ma's watch. Underpinning this rapprochement was the "1992 Consensus" by which both sides commit to the principle of "One China", even if they may interpret that principle differently. Notwithstanding these positive developments, Taiwan is substantially shut out of most international organizations and free trade agreements because of pressure exerted by Beijing on the international community. Taiwan only has formal diplomatic relations with a very few countries, 21 mainly small, poor countries at last count.

To the great dismay of Beijing, this period of closer economic linkages saw the two sides drifting apart politically. There was widespread popular discontent in Taiwan, especially among youth, as the public was experiencing rising inequality, high cost of living and declining opportunity. There was a widespread perception that while the Taiwanese business sector benefited from closer linkages with China, ordinary citizens suffered, as business increasingly moved production facilities, and hence jobs, from Taiwan to the lower-cost mainland.

Ma himself became deeply unpopular. There were public concerns about the growing dependence of Taiwan on China, as Ma has been "selling out" Taiwan to the mainland. These feelings came to a head in 2014, when students and activists ("the sunflower movement") occupied the national parliament for three weeks to block the approval of a free trade agreement, and again when students protested against China-friendly changes to curriculum guidelines in Taiwanese schools. These developments took place in a context where the vast majority of Taiwanese citizens now feel a greater attachment to their distinct Taiwanese identity 
rather than to a Chinese identity. Generational change is fundamentally transforming Taiwan's society and politics, and a majority of its citizens have no interest in unification with China.

It was against this background that Madame Tsai Ing-wen won Taiwan's presidential elections on 16 January 2016 as a representative of the proindependence DPP, with her inauguration taking place on 20 May. China's communist government has always had a deep allergy to the DPP because it fears that it could declare independence. Indeed, Beijing has long threatened military intervention should Taiwan seek to declare independence. Thus the victory of Tsai Ing-wen was a defiance of Beijing's playbook. Taiwan's citizens should have appreciated the benefits of closer economic and person-to-person linkages under the KMT. Ironically, the increase in person-to-person contacts between China and Taiwan seems to have emphasized their differences for the Taiwanese.

Through the presidential election campaign and subsequently, Tsai Ing-wen refused to adhere to the 1992 Consensus and say that Taiwan and China are part of one country. Rather, she tried to dance a fine line between the pro-independence elements from her party and the incessant demands from Beijing that she commit to the one-China policy. Her standard formulation was that she supports the "status quo", meaning neither independence nor reunification, a position which is supported by the majority of Taiwanese people. But this is not good enough for Beijing which does not trust Tsai Ing-wen and the DPP. Beijing continues trying to bully her into formally accepting the 1992 Consensus on one-China.

Since Tsai's election victory, Beijing has been tightening the screws on Taiwan, employing "megaphone diplomacy" to tell Tsai what to do, stopping all official contacts with Taiwan, encouraging some of Taiwan's diplomatic partners to sever relations with Taiwan, pressuring third countries to repatriate alleged Taiwanese criminals to China, pressuring international organizations to withhold invitations to meetings, and sharply reducing the number of mainland tourists visiting Taiwan.

It is clearly Beijing's intention to undermine the government of Tsai Ing-wen, something which is supported by Taiwan's pro-Beijing business elite. But Beijing's actions may also stiffen the backbone of Taiwanese citizens, especially its youth. Clearly, what is required is a period of trustbuilding between the two sides. Looking to the longer term, Beijing needs to learn the merits of soft power. Playing hardball is certainly no way to win the hearts and minds of the people of Taiwan. But it has seen a strengthening in the already warm relations between Taiwan and Japan. 
Any desire of Taiwanese citizens for the reunification of their country with mainland China is frittering away in tandem with growing interference of Beijing in the affairs of Hong Kong, another source of political instability in Asia.

\section{Hong Kong and China: It's Even More Complicated}

After more than 150 years of British colonial rule, Hong Kong was returned to China in 1997. It was to be governed under the "One country, two systems" principle for the next 50 years. Hong Kong could retain a "high degree of autonomy" for its domestic legal and economic system, while China assumed control of Hong Kong's foreign affairs and interpretation of Hong Kong's Basic Law, a mini-constitution negotiated between the British and Chinese governments.

This was seen to be a "win-win" solution. Hong Kong citizens would keep the many freedoms they enjoy. The Chinese economy would continue to benefit from Hong Kong's role as an important gateway to the global economy thanks to its sophisticated financial, legal and logistics sectors, and its sound rule of law, and advanced education system. And both China and Hong Kong would have 50 years to adapt to each other.

But there has been a progressive deterioration in relations between the Hong Kong population and Beijing in recent years, and Beijing is now openly flouting the Basic Law. There are very many factors which have been driving a wedge between Hong Kong and Beijing. Despite Beijing's reputation for meritocracy and wisdom, its choices for Hong Kong's Chief Executive have been anything but meritocratic or wise. Tung Chee-hwa, the first Chief Executive chosen by Beijing, was widely considered to be incompetent and was deeply unpopular with the Hong Kong public. In 2003, some 500,000 Hong Kongers protested against Tung, who ultimately resigned in 2005 , three years into his second five-year term. In February 2017, the second Chief Executive, Donald Tsang, was sentenced to 20 months in prison for corruption, becoming Hong Kong's highestranking official to be jailed. The third Chief Executive, Leung Chun-ying, mismanaged Hong Kong's growing social unrest, and did not seek a second term. Beijing has great hopes for Carrie Lam, who was elected as the new Chief Executive in March 2017.

Hong Kong has experienced growing social unrest in recent years, most notably through the "Occupy Central" and "Umbrella Revolution" pro-democracy protests, about the method for choosing future chief 
executives. Based on the Basic Law and commitments from Beijing, Hong Kong's Chief Executive was scheduled to be elected by universal suffrage from 2017. But Beijing insisted that it choose the election candidates. It insisted that chief executive candidates must "love China and love Hong Kong". Protesters wanted an open nomination process for candidates.

Ultimately, in 2015 pro-democracy members of Hong Kong's Legislative Council ("LegCo") rejected a bill supporting Beijing proposals for the 2017 Chief Executive elections, and Hong Kong's Chief Executive is still not elected via universal suffrage. Relations between Hong Kong and Beijing deteriorated further in 2016 when anti-establishment candidates won 29 out of 70 the Lego seats, including many new faces from the post-Occupy political movement. Beijing then expelled two of these new pro-independence lawmakers from LegCo for "insincere oath-taking" when they severely criticized Beijing.

Although Beijing is very keen for Hong Kong's new Chief Executive, Carrie Lam, to greatly improve relations between the territory and Beijing, this will be a great challenge. In March 2017, Lam was elected by an 1194-member Election Committee, representing only $0.16 \%$ of Hong Kong's population. Lam, a former Chief Secretary for Administration, was Beijing's preferred candidate, but not the preferred candidate of the Hong Kong population. That was former Financial Secretary John Tsang. But Beijing intervened to pressure Election Committee members to vote for Lam.

Hong Kongers see the "hand of Beijing" interfering more and more in Hong Kong affairs, in defiance with the Basic Law. Hong Kong's freedom of the press freedom has been in sharp decline, as the number of physical attacks on journalists has increased. Academic freedom and university autonomy are now increasingly compromised in Hong Kong. There have been cases of academics, who are seen as critical of Beijing, being demoted or coming under attack by pro-Beijing media. China's pervasive political influence over Hong Kong was evident in the 2015 extraterritorial abductions, apparently orchestrated by the Chinese government, of booksellers and others who offended Beijing.

Hong Kong's protests were not only inspired by a desire for democracy. They also reflected a broader feeling of popular discontent concerning the cost of living and housing, poverty and inequality, air pollution and the growing presence of mainland tourists, migrants and business. Way back in 2009, then Chinese Premier Wen Jiabao raised the issue of Hong 
Kong's "deep contradictions" when he pushed then Chief Executive Donald Tsang to do better in maintaining "Hong Kong's harmony and stability", to little effect.

Hong Kongers can see that its government's policies are stacked in favor of the territory's pro-Beijing business elite. More fundamentally, Hong Kong society is becoming deeply polarized between pro- and antiBeijing camps. Increasing numbers of youth have no desire to live under Beijing's rule and favor independence of the territory.

Beijing and Hong Kong leaders have blamed "foreign intervention" (meaning US and UK) for stoking up social unrest, reflecting their state of denial of the genuine grievances of Hong Kong citizens, and divisions in Hong Kong society. In fact, Hong Kong's churches played a quiet but important role in the city's protests, offering food and shelter to demonstrators, with some organizers and supporters citing Christian values as inspiration in their fight. "Christians, by definition, don't trust communists," said Joseph Chan, a political-science professor at Chinese University of Hong Kong.

In his speech in 2017 on the occasion of the 20th anniversary of Hong Kong's return to China, China's President Xi Jinping made clear that protests in support of democracy or independence are unacceptable: "Any attempt to endanger China's sovereignty and security, challenge the power of the central government and the authority of the Basic Law of the HKSAR or use Hong Kong to carry out infiltration and sabotage activities against the mainland is an act that crosses the red line, and is absolutely impermissible ... making everything political or deliberately creating differences and provoking confrontation will not resolve the problems. ${ }^{12}$ " As Beijing becomes more assertive in its relations with Hong Kong, the UK, the country which agreed the Basic Law with Beijing, is very reluctant to criticize Beijing, as it does not wish to upset the strong business and political relationship between China and the UK.

In all likelihood, Hong Kong will continue to be another growing flash point for Beijing to manage. But the biggest flashpoint in China's sphere of influence is North Korea.

\section{North Korean Imbroglio}

North Korea and the US are locked in a stalemate in their struggle over North Korea's growing nuclear threat. How did we land in this imbroglio? Is there a way out? Where is China in this imbroglio? 
No one should blame North Korea for equipping itself with adequate self-defenses. Every country does that. And following the end of the Korean War in 1953, North Korea had more reason to worry than most countries, being "a shrimp among whales". It was indeed surrounded by the giants of the Soviet Union and China, and enemies like South Korea, Japan and the US with its military bases in these latter two countries.

And as the South Korean economy grew rapidly through the 1970s and 1980s, North Korea felt even more vulnerable with its stagnating centrally planned economy. It was during the 1980s that North Korea reportedly began acquiring nuclear technology with lots of help from friends like Pakistan, China and the Soviet Union.

The end of the Cold War and the 1990s was a major turning point in North Korea's modern history. It suffered greatly from the loss of financial support from the Soviet Union, natural disasters and economic mismanagement which led to a massive famine with over 300,000 people dying (it did however benefit from out-of-work Russian rocket scientists who sought work in North Korea). And then Kim Il-sung, the founding father of North Korea, died in 1994, and was succeeded by his eccentric and funloving son, Kim Jong-il.

The Kim dictatorship was spooked by the democratization and adoption of market economics in Russia, and Soviet satellites in Central and Eastern Europe, and Mongolia. The reunification of East and West Germany also exacerbated North Korea's fear of a US desire to reunify North and South Korea.

The lesson that North Korea drew from the end of the Cold War was that rather transforming into a market economy and democracy, it should double down on efforts for regime survival. So it invested heavily in its military capabilities both to act as a deterrent to potential aggressors and to extract economic concessions from the US, Japan and South Korea. North Korea also maintained firm control over the economy (the selfreliance or "juche" philosophy), in contrast to China's market opening.

The US interventions in Iraq, Afghanistan and Libya only confirmed the vulnerabilities that the Kim regime felt, and vindicated its policy of building up nuclear weapons. As a North Korean official once said, "the US would not have invaded Afghanistan if it had nuclear weapons."

Over the past two decades or so North Korea has been playing cat and mouse with the international community over its development of ballistic missiles and nuclear weapons. Following each nuclear test or missile launch, the UN Security Council declares its condemnations, and imposes 
trade and financial sanctions on North Korea, but nothing changes. "Sixparty talks" involving North Korea, South Korea, China, Japan, US and Russia were held from 2003 to 2009. But North Korea sabotaged and walked away from these diplomatic efforts to bring a halt to North Korea's development of nuclear weapons.

Today, the Chinese government is immensely irritated by North Korea, and sees great dangers in its volatile behavior. But China has played a crucial role in the development of the North Korean menace. Some 90\% of North Korea's trade is with China, which is also responsible for the lion's share of its foreign investment. China also hosts thousands of North Korean workers, most of whose wages goes back to the North Korean regime. North Korea is highly dependent on Chinese aid, especially for food and energy.

The Chinese government has allowed North Korean state-owned enterprises to operate in China. They very often buy materials and goods from Chinese and international companies, and then export them to North Korea. Then there are Chinese enterprises like the Dandong Hongxiang Development Company which have been helping North Korea procure raw materials for nuclear weapons. And Chinese banks reportedly hold some of the Kim family assets. At the UN Security Council, China always pushes for moderation and loopholes in sanctions on North Korea. China routinely condemns North Korea's actions and urges it to comply with UN resolutions. But it has never implemented US sanctions seriously.

Why would China support such a heinous regime? It's a question of strategic buffers. As Beijing looks out toward the Pacific Ocean, it feels encircled by a string of US allies - from South Korea and Japan to Taiwan and the Philippines. In other words, the Chinese see North Korea as a critical protective buffer for them against the US.

So China does not want a regime change that would see the US and China battling for control of the Korean peninsula. The last thing that China wants is a failed nuclear state on its border, with the prospect of millions of poor refugees flooding into the country. It is also fearful that regime change could result in a reunification of North and South Korea, with the new state aligned with the US, and American troops sitting directly on its border.

China is of course not the only friend of North Korea. The Pakistan Energy Commission has reportedly sold nuclear materials to North Korea, some of which they have initially bought from China. The recent murder of Kim Jong-nam has highlighted the close links between Malaysia and 
North Korea. And Myanmar's military reportedly has close ties with Pyongyang.

US-North Korean relations have been on a downward slide for many years. But North Korea's rogue activities took a dramatic turn for the worse with the ascension of Kim Jong-un to North Korea's leadership, following the death of his father, Kim Jong-il, in 2011. The new 30-something-year-old dictator, with no direct military or governmental experience, has had to consolidate and assert his leadership to win the necessary loyalty of the military. This has meant eliminating all possible rivals, including his uncle and most recently his half-brother, Kim Jongnam, as well as accelerating his missile and nuclear program. Kim Jong-un conducted two nuclear tests and more than 20 ballistic tests in 2016 alone. And already, he has greeted Donald Trump with a flurry of missile launches in 2017.

After Donald Trump won the US presidential election, outgoing President Barack Obama warned Trump that the first major challenge he would face was North Korea. Indeed, North Korea is widely perceived to be the greatest threat to security, stability and peace in Asia and the rest of the world. Today, North Korea could attack South Korea, Japan, the US base in Guam, and probably even the US mainland with nuclear and other missiles.

The bellicose Donald Trump, surrounded by ex-army generals in his Cabinet, may not be the coolest head for dealing with North Korea. The Trump team announced that the era of Obama's "strategic patience" is over. That all options are on the table, including the military option. The possibility of taking out Kim Jong-un has also been raised. In other words, it is hardly surprising that Kim should have upped the ante in 2017.

The Trump team believes that by ratcheting up the pressure, as the UN did in 2017, North Korea can be forced to give up its nuclear weapons, and to engage dialogue. But the evidence suggests that the more North Korea feels cornered, the more it will still stick to its nuclear weapons. North Korea sees the US and US-supported South Korea as being the principal threats to its security.

Trump had a successful first summit with President Xi Jinping in April 2017 and seemed to have enlisted his support to help control North Korea. However, it only took a couple of months for Trump to realize that China is reluctant to seriously tackle North Korea for fear of destabilizing the regime, despite agreeing to new, tougher UN sanctions. 
Chinese President XI Jinping seems equally fearful of Donald Trump as of Kim Jong-un. He is pushing both sides to de-escalate tensions and engage in dialogue. Both China and Russia are arguing for a "doublefreeze", whereby North Korea would stopping testing weapons, and the US and South Korea would stop their military exercises. At the same time, China is cutely claiming that the North Korean problem is a problem between the US and North Korea, and does not involve China.

Some experts argue that a grand deal is the only hope-freeze or elimination of North Korea's nuclear program in return for economic assistance, a guarantee that the US would not seek to overthrow the regime and a formal peace treaty. But the level of distrust between the US and North Korea is so great that it is difficult to imagine such a grand deal being agreed. It also seems clear that the US will ultimately have to accept North Korea as a nuclear power, and live with that, as it did with China many decades ago. It will also have to accept that unification of the Korean peninsula under South Korea would never be accepted by China, and is not a realistic option.

Although China wants political stability on the Korean peninsula, it is also very keen that any resolution of the North Korean problem results in a weakening of the US position in Asia-such as by a reduction in the US commitment to defend South Korea through a cut or even removal of US troops from the South. Even though there is no love lost between China and North Korea, the North will have done China a great favor if it manages to weaken the alliance between US and South Korea.

Trade is another factor which is working in China's favor. South Korea is becoming increasingly dependent on the Chinese market. And, depending on the outcome, Donald Trump's threat to renegotiate or even abolish the US-Korea Free Trade Agreement could help tilt South Korea's trade further toward China. The South China Sea is another area where China has stolen a march on the US and its partners, and will remain a strategic flashpoint for at least some time to come.

\section{China Snaffles the South China Sea from Its Southeast Asian Neighbors}

Myriad countries surround the South China Sea, namely China, the Philippines, Vietnam, Brunei, Malaysia and Taiwan. It is thus not surprising that since time immemorial these same countries should have had 
overlapping claims to these waters, their reefs, islands and atolls, including the Spratly Islands, Paracel Islands and Scarborough Shoal. The South China Sea is a massive 1.4 square million miles, an area the size of Mexico and larger than the Mediterranean Sea.

In 1947, China issued a map of its claims, which encompassed about $90 \%$ of the entire South China Sea. This claim has come to be known as the "nine-dash-line", which reflects the pictorial representation of China's claim. In 2009, China submitted a diplomatic note to the UN including the nine-dash-line on a map. This overlaps with claims by the Philippines, Vietnam, Malaysia, Indonesia and Brunei. According to the UN Convention on the Law of the Sea (UNCLOS), to which China is a signatory, countries have special access to marine resources, including fisheries, oil and gas, in the area up to 200 nautical miles from their shores, called exclusive economic zones. Most of the South China Sea is very much further from China than that distance.

In 2012, China forcibly seized control of the previously unoccupied Scarborough Shoal during a standoff with the Philippine Navy. The Scarborough Shoal is only 100 miles from the Philippines, but 500 miles from China. Under a 2012 deal mediated by the US, China and the Philippines promised to withdraw their forces from the shoal until a deal over its ownership could be reached. The Philippines complied with the agreement and withdrew. China, however, did not abide by the agreement and maintained its presence at the shoal, effectively militarizing it. Then Philippine President Benigno S. Aquino III later compared China's behavior to Nazi Germany's annexation of Czechoslovakia.

With no other recourse, the Philippines took China to a UNCLOS tribunal. China boycotted the tribunal's proceedings on the basis that it had indisputable sovereignty over its claimed area and that the tribunal did not have the authority to deal with this matter. Reflecting its indignation and contempt for the Philippine challenge, China embarked on massive construction exercise in the South China Sea, building or expanding at least seven artificial islands, some with airports on which military aircraft can land.

This was clearly a ploy to create "facts on the water", which are irreversible. It is dubbed the great wall of sand by senior US officials. In 2014, China also deployed a deep-sea oil rig within Vietnam's exclusive economic zone, leading to a drawn out dispute. President Obama's reluctance to stand up to Beijing during the early stages of its blatant land reclamation activities in the South China Sea only emboldened Beijing to 
continue with its buildup and militarization of artificial islands. And the US' subsequent freedom of navigation exercises through the South China Sea are a case of "too little/too late".

What is at stake in the South China Sea? According to the US Department of Energy, there would be 11 billion barrels of oil in the South China Sea, and 190 trillion cubic feet of natural gas. It is also a very rich fishing ground, which is now most regrettably being depleted. Some $\$ 5.3$ trillion worth of international trade passes through the South China Sea, about $30 \%$ of global maritime trade. And $\$ 1.2$ trillion of this is US trade. Japan and Korea also rely heavily on the South China Sea for their supply of energy and other raw materials, and also as an export route. Some $60 \%$ of Australia's trade passes through the South China Sea. Not surprisingly, non-claimants want the South China Sea to remain as international waters, rather than being privatized by China. Circumnavigating the South China Sea would drive up commercial shipping costs.

More fundamentally, the international rule of law is at stake. China is a country that has benefited from the multilateral system, but is now seen by most to be flagrantly flouting this very system. As former French Defense Minister Jean-Yves Le Drian said: "If the Law of the Sea is not respected today in the South China Sea, it will be threatened tomorrow in the Arctic, the Mediterranean or elsewhere." Vladimir Putin and other authoritarians are watching.

The UNCLOS arbitration tribunal accepted 14 of the 15 claims by the Philippines. In particular, it ruled that there is no legal basis for any Chinese historic rights within the nine-dash line. The tribunal also ruled that none of the disputed maritime features in the Spratly Islands, including Scarborough Shoal, Gaven Reef and Fiery Cross Reef, are islands under the law of the sea (they are instead "rocks"). Thus, they do not result in entitlements to a 200 mile exclusive economic zone or continental shelf. In other words, Scarborough Shoal-the scene of the standoff between the Philippine Navy and China-is within the Philippines' maritime domain, rather than China's. The tribunal also found that China's land reclamation and island-building activities had caused irreparable damage to the coral reef ecosystem and breached the UNCLOS treaty. And in the case of Scarborough Shoal, China breached the treaty by undertaking land reclamation without the authorization of the Philippines.

China is legally bound by the UNCLOS decision, by virtue of being a signatory to the treaty. But there are no enforcement mechanisms, and China never had any intention of respecting the judgment. The Chinese 
government lambasted the tribunal's judgment, claiming that it is part of an American conspiracy. On the Philippine side, there were great public celebrations in this nation that is tired of being bullied by more powerful nations.

But the UNCLOS decision was delivered just a matter of days after Rodrigo Duterte assumed the presidency of the Philippines, following the six-year term of Benigno Aquino III. While Aquino's foreign policy was closely aligned with the US, its treaty ally, Duterte has shifted course to an "independent" foreign policy. His firebrand and colorful personality was in evidence when he visited China in 2016 and said "I announce my separation from the United States, both in military but economics also ... America has lost it." He announced the Philippines would align itself with China and Russia.

Duterte's approach has been to seek cooperation rather than conflict with China over the South China Sea. Indeed, as he garnered \$24 billion worth of investment and financing agreements from China, he has clearly sought to use the South China Sea as a bargaining chip with China. China has allowed Philippine fishermen to return to the Scarborough Shoal. Meanwhile, China has only accelerated its constructions and militarization of its artificial islands.

Perhaps realistically, Duterte said "We cannot stop China from doing its thing. Even the Americans were not able to stop them ... So what do you want me to do? Declare war against China?" The Chinese government is surely celebrating that this Scarborough Shoal incident has enabled it to drive a wedge between the Philippines and the US which had hitherto been the closest of allies. Malaysia, another important claimant to the South China Sea, has also been silent following another large signing of trade deals. The only Asian country left challenging China in the South China Sea seems to be Vietnam.

The new US administration of President Trump has made many feisty comments regarding China's actions in the South China Sea. Secretary of State Rex Tillerson even said that US would prevent China from accessing its own artificial islands in the South China Sea. And even though this region is a long, long way from Washington, the US does have enduring interests in the dispute, namely, freedom of navigation and overflight, support for the rules-based international order and the peaceful resolution of disputes. But it seems hardly likely that President Trump will invest too much political capital in this dispute, when most of the claimants are no longer fighting for the issue, and when he has bigger fish to fry with China. 
In sum, China has achieved a stunning victory in the South China Sea over its Southeast Asian neighbors and weakened ASEAN in the process. And while the US may have kept its powder dry for possible future conflicts, its inaction seems to have only emboldened China and weakened the credibility of the US as a security partner in East Asia.

\section{China Fractures ASEAN}

ASEAN, the Association of Southeast Asian Nations, represents Asia's most successful effort at regional cooperation and integration. But it is now being increasingly fractured and dominated by China.

China was already on the minds of ASEAN's founding fathers in 1967 when the governments of Indonesia, Malaysia, the Philippines, Singapore and Thailand decided to join forces. Security was of paramount importance during this Cold War period, when ASEAN was concerned about the threat of communism coming from China and Vietnam. During the 1960s, Mao Zedong supported communist insurgency movements in Southeast Asia. Over the years, ASEAN has gradually expanded with the membership of Brunei (1984), Vietnam (1995), Laos and Myanmar (1997) and Cambodia (1999).

Though huddling between Asia's giants of China and India, with their billion-plus populations, ASEAN is an important regional player. Its population of 622 million is almost double America's 320 million and also more than the European Union's (EU) 506 million. As a group, ASEAN is an economic powerhouse, being the world's seventh biggest economy. And while ASEAN has not grown as quickly as China or India, the group has been one of the world's fastest-growing markets with an annual average growth rate of $5.1 \%$ from 2000 to 2013 . Indonesia, with a population of 260 million, accounts for almost $40 \%$ of ASEAN's GDP.

With the end of the Cold War and the emerging globalization of the world economy, ASEAN was transformed into an important organization for economic cooperation, as well as political and social-cultural cooperation. The ASEAN Free Trade Area was signed in 1992, and now includes all ten ASEAN members. Building on this, in 2015 the ASEAN Community came into force with economic, political-security and socio-cultural pillars.

With international squabbling, rather than cooperation, being the currency in Northeast and South Asia, ASEAN has become an effective meeting ground and fulcrum for Asian cooperation. Six other regional 
partners-China, Japan, Korea, Australia, New Zealand and India-have free trade agreements with ASEAN, and talks are under way to transform them into a single undertaking, the Regional Comprehensive Economic Partnership (RCEP).

ASEAN takes a leading role in security dialogue in Asia through the ASEAN Regional Forum (ARF), which was established in 1994, and now includes 27 members. The ARF is unique in that North Korea is a member, and its 2017 meeting provided an important opportunity for discussions with the North on its nuclear and missile programs. ASEAN is also in a leadership position of the East Asia Summit which is a regional leaders' forum for strategic dialogue and cooperation on key challenges facing the East Asian region.

While concern about the threat of Chinese communism was a key motivator for the creation of ASEAN, China has since become a leading partner of the ASEAN countries, in many cases now overtaking Japan, which had previously been the leading partner. China is ASEAN's most important trading partner, with the least developed countries of Cambodia, Laos, Myanmar and Vietnam being the most reliant on Chinese trade. China is the most important source of FDI in Cambodia, Laos and Myanmar, and the second most important in Vietnam, even though it is not yet a major investor in ASEAN overall. China has also been investing heavily in infrastructure in ASEAN countries bordering China, namely Laos, Myanmar and Vietnam. And Chinese tourists are now flooding ASEAN countries, bringing muchappreciated revenues.

In short, China's rise is exerting a powerful pull over ASEAN economies and politics, and the Chinese government now routinely tries to lord it over ASEAN in their regular meetings. China's contempt for ASEAN was on full display in a 2010 meeting in Hanoi, Vietnam, when China's then foreign minister Yang Jiechi famously said "China is a big country and you are small countries and that is a fact" (Yang was subsequently promoted to the Chinese State Council). Many cite this comment as the trigger for US President Obama's pivot to Asia.

China's divide-and-rule of ASEAN has been in full evidence as it succeeded in pressuring several ASEAN countries to refrain from supporting the decision of the arbitration tribunal of the UNCLOS in favor of the Philippines and against China. For the moment, China seems to have 
bought off the claims of Malaysia and the Philippines with packages of trade, investment and assistance. Brunei is too small to stand up to China. Only Vietnam is seriously attempting to push China back.

Throughout this process, ASEAN has been totally ineffective at working as a group to counter China's claims to the South China Sea. For example, Cambodia, Beijing's most loyal stooge, has blocked or watered down mentions of the South China Sea dispute in ASEAN ministerial communiqués, which are agreed by consensus. Laos and Malaysia have also been weak on the South China Sea issue due to Chinese pressure. And Thailand has been moving into Beijing's orbit as the US has criticized the role of the military in Thai politics and the deterioration in human rights, following the 2014 military coup.

A possible South China Sea code of conduct between ASEAN and China has been talked about since 2002, but China has always used stalling tactics. Now that China has achieved its goal of seizing the South China Sea, discussions are now back under way, but are moving slowly, as China rushes ahead with its construction and militarization. And while the Philippines and Vietnam have pushed for a legally binding code, China is insisting on a non-binding code. China will not accept an independent dispute settlement mechanism. And above all, China prefers bilateral negotiations to resolve all disputes, so it can play the carrots and sticks game to submit smaller countries to its will.

As China seeks to create a sphere of influence in East Asia, ASEAN is becoming a casualty of China's realpolitik. ${ }^{13} \mathrm{~A}$ strong and united ASEAN could protect the region's interests in the South China Sea and elsewhere. But it is in China's interest to have a weak and divided ASEAN, and China is succeeding famously in this regard.

The US has long had close relations with most ASEAN countries. But there was some fallout between the US and Malaysia, the Philippines and Thailand during the Obama administration. And Donald Trump paid no attention to Singapore's warning about the importance of the TransPacific Partnership (TPP). Overall, the general feeling in ASEAN is that the US' interest in and commitment to the region is waning. While Japan is becoming more active and competing with China for regional influence, it has difficulty vying with China. In particular, China's AIIB and the BRI are proving to be very important instruments for strengthening relations between Beijing and individual ASEAN countries. 


\section{China's LeAdership For Asian InFrastructure}

Massive investments in infrastructure have been a major element in China's development strategy. They have also become the key instrument for China's efforts to re-shape international cooperation in Asia and beyond.

Under Chinese leadership, AIIB opened for business in 2016. This initiative was motivated by the US Congress' delays in approving an increase in the weight of China and other emerging economies in the IMF and World Bank. It was also inspired by China's feeling that the multilateral international system was still too dominated by the West.

The Obama administration pressured all of its friends and allies not to join the AIIB. The US saw it as a competitor for the US-led World Bank and the Japan-led Asian Development Bank (ADB). But ultimately the UK broke ranks, and was then followed by virtually all other advanced and emerging economies. At last count the AIIB had 56 member countries. Japan and the US are the only major countries to have not signed up. And in acts of contrition, the World Bank and ADB are now cooperating very closely with the AIIB.

The new bank's lending may be only slowly getting off the ground, but it already has more members than the $\mathrm{ADB}$ and its authorized lending limit is also higher than the ADB's. The new competition from the AIIB has seen the ADB streamline its lending procedures and rush to approve new lending. Overall, the AIIB is seen as great success for Chinese leadership in Asia and the multilateral system more generally. After all, Asia's infrastructure needs are enormous, some $\$ 1700$ billion a year in investments in power, transport, telecommunications and water through 2030, according to $\mathrm{ADB}$ estimates. For its part, the US is seen have egg on its face from its strategic blunder in opposing the AIIB. If the US really wanted China to become a responsible stakeholder in the international system, it should never have opposed China's initiative to create the AIIB.

While the rivalry between the ADB and the AIIB is capturing international attention, the biggest race to finance Asia's infrastructure is between Japanese and Chinese national institutions. Lending by the Japan Bank for International Co-operation and the Japan International Co-operation Agency dwarfs that of the ADB, while the China Development Bank and the Export-Import Bank of China together lend many times what the AIIB will lend when it hits cruising speed.

"This funding race has many upsides," says Robert Wihtol of the Manila-based Asian Institute of Management. "The competition is 
increasing the total financing available for Asian infrastructure. And having numerous financial institutions increases the scope for joint financing, which can spread the risk inherent in large projects."

Mr. Wihtol cautioned, however, that the race to finance Asia's enormous infrastructure also has its downsides. "Geopolitical rivalries can see projects of questionable value get rapidly approved, without proper preparation or cost-benefit analysis, thereby saddling borrowers with burdensome debt, as we have seen in Sri Lanka," he says. "And there are many examples of lenders not taking sufficient account of sovereign risk, most notably in the case of Venezuela. In this context, the advantage of multilateral banks like ADB and AIIB is that they conduct thorough risk analysis and due diligence." 14

\section{Belt and Road Initiative for a Sinocentric Asia}

The BRI is another Chinese initiative to improve infrastructure, notably across Eurasia. In the eyes of many, however, it is also an initiative that seeks to advance China's hegemonic ambitions in Asia.

It was in 2013 that Chinese President Xi Jinping launched his BRI with the aim of connecting major Eurasian economies through infrastructure, trade and investment. This initiative is a key element in Xi's "China Dream" for the great rejuvenation of the Chinese nation, and for China to become the paramount Asian country. Xi has invited BRI partners to join a "Community of Common Destiny".

The BRI comprises two main elements-the Silk Road Economic Belt and the 21st Century Maritime Silk Road. The Silk Road Economic Belt will be a network of high-speed railways, roads, pipelines and utility grids which will provide improved connections between China and Central Asia, parts of South Asia, the Middle East and ultimately Europe. This will reduce China's sense of vulnerability due to its reliance on Straits of Malacca and the South China Sea for its energy imports from the Middle East. The Maritime Silk Road will create ports and other infrastructure to better connect China with Southeast Asia, South Asia, the Middle East, East Africa and Europe (China already owns the Greek port of Piraeus).

Six major economic corridors are planned, including the New Eurasian Land Bridge, China-Mongolia-Russia, China-Central Asia-Western Asia, Indo-China Peninsula, China-Pakistan and Bangladesh-China-IndiaMyanmar. Some 68 countries, representing 55\% of world GDP and 70\% of world population, have signed up to the BRI. ${ }^{15}$ 
The financing needs of the BRI will be enormous. China's total investment in the BRI over the next decade is expected to reach $\$ 1.6$ trillion, according to preliminary estimates by the China International Capital Corporation. This exceeds by many times the capital of the ADB, the AIIB, the New Development Bank and China's Silk Road Fund, which will only play small roles in the overall financing. Much of the funding will come through loans from the China Development Bank and other Chinese state-owned banks.

The BRI has a different model from other regional economic initiatives. For example, agreements like the RCEP and TPP mainly concern trade liberalization and policy reform, whereas the BRI focuses on improving infrastructure connectivity. Further, the BRI is not an organization like the EU or a multilateral agreement like the RCEP or TPP. It is a Sinocentric "hub-and-spoke" arrangement of bilateral agreements between China and each of the participating countries. And these are only political, not legal, agreements. This means that China, as the dominant partner in each of these agreements, will have a tremendous ability to set agendas and advance its own interests.

In this sense, the BRI is not only inspired by the legendary trade along the Silk Road, but as David Arase once remarked, it is a "backward looking vision of the future" which seeks to recreate a Sinocentric regional order from the past. ${ }^{16}$ But the BRI is clearly the signature project of President $\mathrm{Xi}$, and will remain a very high priority during his presidency, even if it is unwieldy and perhaps overly ambitious.

The BRI has generated mixed reactions. Many have welcomed China's bold initiative, which promises to help address Asia's massive infrastructure deficit, and which could provide a much needed boost to economic growth through the market integration it will foster. And through the BRI China is proving to be a more reliable partner than the US, which abandoned the TPP after several years of hard work by all the negotiating countries.

However, the ratings agency Fitch has also highlighted the risks for China's banking sector emanating from the BRI (also known as OBOR, "one belt, one road"). ${ }^{17}$ "OBOR is driven primarily by China's efforts to extend its global influence and relieve domestic overcapacity", notes Fitch, and "there is a risk that projects ... could fail to deliver expected returns." Fitch has doubts that China's banks can identify profitable projects"After all", says Fitch, "Chinese banks do not have a track record of allocating resources efficiently at home, especially in relation to infrastructure 
projects." "Meanwhile, local politicians have an incentive to associate themselves with marquee projects. This subjugation of market forces means there is a heightened risk of projects proving unprofitable."

The asymmetries of size and power between China and the participating countries make the BRI unique and challenging. As countries like the Philippines, Vietnam and Japan have discovered in recent times, disagreements with China can lead to punishment by the Chinese government in the form of reduced market access and diplomatic exclusion. China will not accept the role of international tribunals to resolve disputes, such that international law will not play a role in BRI. ${ }^{18}$ And China's assertive behavior in the East and South China Seas has only made BRI partners suspicious of its motives.

The benefits for partner countries can be questionable, as most BRI infrastructure projects will be financed by Chinese state-owned banks, and built by state-owned Chinese companies, using Chinese workers and suppliers. Partner countries can be left with an enormous debt to the Chinese banks, sometimes for projects of dubious value.

On the ground, China has been running into opposition. The upgrade of Sri Lanka's deep-sea port in Hambantota saw street protests and opposition by legislators because of the perceived generous concessions to China. As the port quickly became a loss-making white elephant, the government was forced to look for a way out, which eventually took the form of a debt-to-equity swap granting state-controlled China Merchant Holdings control of the port and a 99-year concession to develop its operations. ${ }^{19}$ There have also been reports of the Chinese People's Liberation Army's navy using this commercial port for visits of military submarines. ${ }^{20}$

What are the prospects for the BRI looking forward? According to Paul Keating, former Australian Prime Minister, and now advisor to the China Development Bank, "What we're going to see is a reasonably obvious economic colonisation of the 50-odd states between the western border of China up to at least western Europe." 21

The BRI will no doubt encounter many hiccoughs along the way, and its full ambitions may never be fully met. But the attractiveness of Chinese money to finance Asia's massive infrastructure deficit will be irresistible to many countries, even if it means becoming part of China's sphere of political influence.

One hiccough for China's BRI has been the frictions that it has generated with India, Asia's other behemoth. 


\section{Chinese and Indian Frictions}

China has joined forces with India's arch enemy, Pakistan, to build the China-Pakistan Economic Corridor. This initiative is a bold package of investment projects ( $\$ 441 / 2$ billion or about $16 \%$ of Pakistan's GDP), in energy and transport infrastructure, financed by Chinese loans and FDI. The Corridor is a "flagship project" which will link the Chinese city of Kashgar to the Pakistani port of Gwadar, thereby potentially connecting the Silk Road Economic Belt with the Maritime Silk Road, which would enable China's energy imports from the Middle East to circumvent the Straits of Malacca.

The IMF has issued warnings about the project and its management. It noted that Pakistan's current account deficit could widen during the investment phase, and that over the longer term, Pakistan will need to manage the repatriation of profits and loan repayments of Chinese investors. As the IMF also warns sharply, "There is a need to ensure sound project evaluation and prioritization mechanisms based on effective costbenefit analysis ... The procurement process should be transparent and competitive, and there is a need to ensure transparency and accountability in project management and monitoring." 22

India has several profound concerns about the Economic Corridor. During a 2015 visit to Beijing, Indian Prime Minister Narendra Modi reportedly told Chinese leaders that China-Pakistan Economic Corridor is "unacceptable" because it passes through Pakistan-occupied Kashmir, an area claimed by India. India fears that Pakistan's port of Gwadar could become a Chinese naval base, rather than a commercial hub.

Beyond the China-Pakistan Economic Corridor, India has many understandable concerns now that China's quest for regional dominance seems to have extended to the Indian Ocean, after conquering the South China Sea. In particular, India fears being encircled in the Indian Ocean by Chinese-financed ports. China now has a majority stake in Sri Lanka's Hambantota port, which straddles the world's busiest east-west shipping route. Bangladesh has inked memorandums of understanding with two Chinese companies for the construction of components of the Payra deepsea port. China is reportedly seeking an $85 \%$ stake in the strategically important deep-sea port of Kyauk Pyu in Myanmar on the Bay of Bengal. And the Maldives has leased an island close to Malé airport to a Chinese company for 50 years. 
As India's former Defense Minister, Pallam Raju, once remarked, there is a need for more information sharing regarding the BRI. "China is not necessarily a benign power, and it should be more transparent," said Mr. Raju. ${ }^{23}$ So it was not entirely surprising that when China hosted a BRI Summit in May 2017, India should boycott this meeting which brought together leaders and officials of 130 countries, 68 of which had already signed on to the Initiative. The Indian government reiterated its objections, namely that it includes projects in land belonging to India, it could push smaller countries into crushing debt cycles, it could destroy the ecology and disrupt local communities, and that China's agenda was unclear, suggesting that the BRI was more about enhancing its political influence, not just its physical networks.

Concerns over the BRI come on top of seven decades of on-again, offagain frictions between China and India. There are several border disputes along their shared $3500 \mathrm{~km}$ border, and China claims the Indian state of Arunachal Pradesh as its own. The two nations fought a war in 1962, which China won decisively, and there have been several other conflicts and skirmishes. The most recent dispute occurred in mid-2017, when India responded to Bhutan's cry for help as China was found to be building a road in an area disputed by Bhutan and China. The two great powers then spent over two months facing each other in a military standoff.

There have been many other factors driving frictions between Asia's two great powers. India sees China as a source of regional instability through its support for Pakistan, and in particular its nuclear weapons program. India was never happy about China's annexation of Tibet, which it had considered an important strategic buffer. For its part, China is not happy that its nemesis, the Dalai Lama, lives in India, where he has set up a Tibetan government in exile in the city of Dharamshala. In more recent years, trade and investment ties between China and India have boomed, and China has become India's largest trading partner. But the balance has been heavily in China's favor. More generally, Chinese media and commentators often have a condescending attitude toward India, and the perceived inefficiencies of its chaotic democracy.

It is not surprising that in recent years India has pivoted its foreign policy toward forging partnerships with the US, Japan and Southeast Asia. For example, the navies of India, Japan and the US undertake a joint annual exercise, "Exercise Malabar". And India's Look East policy seeks to cultivate relations with Southeast Asia as a counterweight to the strategic influence of China. 
As we have argued, India's economic size will progressively challenge China's over the course of the twenty-first century and will likely result in an intensification of frictions between these two great Asian powers. And the Indian Ocean could well become a theater for future conflict.

China's growing assertiveness in East Asia instigated US President Barack Obama's "pivot" to Asia.

\section{OBama’s Pivot to Asia}

The election of Barack Obama promised a new phase in America's relationship with Asia, following George Bush's costly decade of Middle East wars. In a speech in Tokyo in 2009, the first year of his presidency, he billed himself as "America's first Pacific president" (he was born in Hawaii), promising the nations of Asia "a new era of engagement with the world based on mutual interests and mutual respect".

Obama was very right to focus on Asia. With some 60\% of US trade being with the Pacific region, Asian maritime and regional security are vital US interests. Japan and China are the biggest foreign holders of US Treasury Securities, with Hong Kong, Taiwan and India also being important investors. And the US has long-standing security ties with Japan, Korea, the Philippines, Thailand, Taiwan and Singapore, with a combined 80,000 troops stationed in Japan and Korea.

Asian Americans, which now make up 6\% of the nation's population, are also America's fastest-growing and most successful migrant grouptheir average household income is some 30\% higher than Americans overall. China, India and Korea account for over half the foreign students in the US, with Vietnam, Taiwan and Japan also being in the top 10. Japan, China and Korea are among the top 10 source countries for foreign tourists in America. All these factors generate deep human and emotional connections between the US and Asia.

It was perhaps not surprising that in 2011 President Obama should decide to deepen his engagement through his "pivot" to Asia. The US pivot was an attempt at a longer term strengthening of America's already deep engagement with the Asia-Pacific region, in light of the region's growing importance, and also in light of the reverberations from the rise of China. On the military side, it was planned that by 2020 , the US navy would reposture its forces from today's roughly $50-50 \%$ split between the Pacific and the Atlantic to about a 60-40 split between those oceans. In the economic area, the TPP was the key piece. Obama's defense secretary 
Ashton Carter once said that the "TPP is as important to me as another aircraft carrier."

President Obama's pivot to Asia was subject to much criticism. Its initial emphasis was on the military dimension. Some argued that Obama's pivot reflected the US desire to "contain" China, and that by exacerbating strategic rivalry, the US actually provoked China's subsequent assertive behavior, notably in the South China Sea. Others argue that it was all talk and no action, with very few substantive results.

US bilateral relations with other Asian countries were a mixture of sweet and sour through the Obama administration. President Obama had bromances with Manmohan Singh and especially Narendra Modi, the two Indian prime ministers who overlapped with his presidency. They had a lot in common, coming from the world's two largest democracies, and sharing a concern about China's assertive behavior. Economic and military cooperation also strengthened greatly Vietnam, a member of the TPP. Washington also lifted its decades-long embargo on selling lethal arms to Vietnam, despite the war history between the two countries. The Obama administration fostered a warm relationship with Myanmar and its de facto leader Aung San Suu Kyi, even though there were great concerns about the country's appalling treatment of its Rohingya minority.

At the same time, Obama oversaw a cooling of relations with a number of countries. In the case of Thailand, the 2014 coup and the failure of the military to restore democracy, together with growing human rights abuses, led to strained relations with one of America's closest friends in Asia. Thailand's military government has since moved closer to China. Obama had made great efforts to foster warm relations with Malaysia, a moderate Muslim country, for its help in fighting radical Islamic terrorism. In 2014, he even played golf with Malaysian Prime Minister Najib Razak in Hawaii. But the US Justice Department's lawsuit concerning Malaysia's corrupt sovereign wealth fund, IMDB, saw a fading of the friendship.

After a strengthening in US-Philippines military cooperation under President Aquino, the new Philippine President Rodrigo Duterte distanced his country from the US, following its criticism of human rights abuses in the country's murderous war against drugs. In the case of both Malaysia and the Philippines, Beijing has been able to step into the gap left the US and assuage objections to its military buildup in the South China Sea by through generous trade, investment and aid packages. Despite America's infatuation with Myanmar's Aung San Suu Kyi, she is also cultivating close links with China. And like his predecessors, Obama was unable 
to put a halt to North Korea's missile and nuclear arm development. And lastly, Obama's Asian diplomacy was guilty of one really big blunder, its opposition to the Chinese-led AIIB.

Despite the great promise of America's first Pacific president, and his pivot to Asia, America's footprint in the region weakened during the Obama presidency. Competing with China for Asian friendships is increasingly difficult for the US. Short-term imperatives in the Middle East, Russia and Washington will also always draw US attentions away from the longer term strategic importance of Asia. The Chinese provide lots of financial and infrastructure to buy friendships, which the US does not do. China also uses trade as an extension of their foreign policy, and is not concerned about ethical issues like corruption and human rights.

Ever since Nixon's trip to China in 1972, American policy elites had believed that encouraging China's participation in the global economy and global governance would result in China becoming a responsible stakeholder in the post-war multilateral system, and becoming "more like us". In this context, the Obama administration was also the time when America discovered that democracy, rule of law and human rights were not coming to China any time soon, as the Chinese Communist Party under President Xi Jinping was tightening its grip on power. Moreover, even though China had been a great beneficiary of the post-war order, in tandem with its rise in power, China is intent on challenging the post-war order, and pushing America out of Asia.

A deterioration in US-China relations under the Obama administration set the stage for China to become the whipping boy of Donald Trump's presidential election campaign.

\section{Trump's Potshots at Asia}

During the election campaign and before his inauguration, Donald Trump had much to say about Asia and China in particular. As we have discussed above, Trump was very critical of trade relations with China, the TPP, China's military island-building program in the South China Sea and its lack of help to contain North Korea. Trump also threatened to make Japan and Korea pay more for the US military troops and assets that are defending them, and suggested that they could acquire nuclear weapons so that they could assure their own defense. Trump also questioned the "OneChina Policy", and spoke by telephone with Taiwan President Tsai Ing-wen. 
The Trump administration moved quickly into action on the Asian front, as it withdrew the US from the TPP. At the same time, Trump's rhetoric on trade policy has been evolving and softening, as he is now arguing for both free and fair trade. He is concerned about the lack of reciprocity in trading relations, and would now like US trade policy to focus on bilateral, rather than multilateral deals, to secure better market access. Despite the softening in Trump's trade rhetoric, there remains a strongly protectionist undercurrent, as Trump's overriding trade policy goals are reducing the US' bilateral trade deficits (notably with China, Japan and Korea), and bringing back manufacturing jobs to America.

To the great disappointment of China and the rest of the international community, President Trump has also withdrawn the US from the Paris Climate Change Agreement, which relied on strong US-China cooperation. China and the EU are now positioning themselves as global leaders in the fight against climate change, despite China's appalling domestic environment, and the poor environmental performance of China's investments in Africa and Latin America.

Trump officials reaffirmed the US commitment to its alliances with Japan and Korea, while Trump himself indicated his support for the "OneChina Policy" in a telephone conversation with Chinese President Xi Jinping. This is seen to have been a big back down for Trump, as Xi reportedly refused to talk with him until Trump honored the One-China Policy.

Trump had a successful first summit with President Xi Jinping in April 2017, and seemed to have enlisted his support to help control North Korea. However, it only took a couple of months for Trump to realize that China is reluctant to seriously tackle North Korea for fear of destabilizing the regime. The XI-Trump honeymoon was then over, almost as quickly as it started, when the Trump administration announced sanctions against Chinese entities for their dealings with North Korea, also announced actions against China's alleged dumping of steel exports, gave a green light for a \$1 billion arms sale to Taiwan, and sailed a US destroyer through the Chinese-occupied South China Sea. And Trump's launching in August 2017 of an investigation into China's alleged theft of US intellectual property has deeply troubled the Chinese government, and raised the specter of a possible trade war between China and the US.

It also seems that Donald Trump's administration is planning to defy Winston Churchill's advice that "to jaw-jaw is always better than to warwar". His 2017 budget proposal involves increasing funding to the US 
military by $9 \%$, while cutting the State Department's diplomacy and foreign aid by a combined 28\%, and also the Environment Protection Agency by $31 \%$. "There is no question that this is a hard-power budget; it is not a soft-power budget," said Mick Mulvaney, the director of the Office of Management and Budget. While the US Congress is seeking to restore funding for these agencies, Trump's budget proposals certainly set the tone for his administration's approach to international relations. Trump's hard-power approach to international relations was soon evident in its approach to North Korea. Indeed, North Korea has been virtually the sole focus of Trump's Asia policy.

Countries like China, India and the Philippines which rely heavily on migrants' remittances could suffer from President Trump's tightening of migration policies. These three countries account for almost all of America's 1.5 million illegal migrants coming from Asia, and 13\% of all illegal migrants. Asia could also be hit by a tightening up of $\mathrm{Hl}-\mathrm{B}$ visas, of which India is the principal beneficiary.

President Donald Trump's working assumption is that Asia has been "ripping off" America in different ways. For their part, many Asian countries also have concerns about the US. The big policy switch-around from one administration to another can undermine the reliability of the US as a partner. For example, in an interview before the US elections, Singapore's Prime Minister Lee Hsien Loong said that a failure to ratify the TPP "would be a very big setback for America". "Your standing goes down with many countries around the world," Lee said. "After you have gotten Vietnam to join, after you have gotten Japan to join, after Japanese Prime Minister Shinzo Abe has made very difficult arrangements on agriculture, cars, sugar, and dairy. Now you say, 'I walk away, that I do not believe in this deal.' How can anybody believe in you anymore?"24

In Australia, arguably the US' most loyal ally, commentators are calling for a rethink of the country's historic relations with the US. For example, Australia's former foreign minister Gareth Evans has said that Trump is "manifestly the most ill-informed, under-prepared, ethically challenged and psychologically ill-equipped president in US history" and that Australia should reduce its dependence on the US alliance and accept China as a legitimate "global rule maker". And as former Washington Post reporter, Paul Blustein, has remarked, it is certainly clear that "this administration has no respect for international institutions."

Overall, following the election of Donald Trump, Asia is now faced with a likely deterioration in key factors that have driven its 
development-an open US market, a relatively benign security environment and a stable global economic system. More generally, the US election campaign and the turmoil of the Trump administration have greatly undermined the credibility of the US as an indispensable strategic power in Asia. Its moral ascendancy and soft power have been greatly diminished. At the same time, China is now the most important economic partner of most Asian countries, is providing much assistance and financing infrastructure without any policy conditionality and seems like a steadier, more reliable partner.

\section{The Future of Peace and Harmony in Asia}

The relative peace that Asia has enjoyed these past seven decades has been key to the region's economic renaissance. But the future of peace in Asia cannot be taken for granted. Asia is in the midst of a great power transition, as China is becoming the region's dominant power, and the US is receding. But this transition may not be smooth, as it involves a power struggle between these two giants, which are both burdened by immense domestic fragilities and weaknesses while they try to assert their regional and international leadership at the same time.

The great power transition under way is of historic proportions. As Singapore's founding father and intellectual giant Lee Kuan Yew once cautioned, "the size of China's displacement of the world balance is such that the world must find a new balance. It is not possible to pretend that this is just another big player. This is the biggest player in the history of the world. ${ }^{25}$ " And yet, for the first three decades of its high growth period, China kept a relatively low profile in international politics. Chinese leaders heeded the caution of great leader Deng Xiaoping that China should "observe calmly; secure our position; cope with affairs calmly; hide our capacities and bide our time; be good at maintaining a low profile; and never claim leadership". This is widely known as the "hide and bide" strategy.

But following the outbreak of the global financial crisis in 2008, and especially since the ascension of Xi Jinping to Chinese leadership in 2012-2013, China has been doing much less hiding and biding. Its new assertive posture is evident in its aggressive behavior toward Japan, its annexation of the South China Sea, its divide-and-rule tactics vis-à-vis ASEAN, its economic sanctions against countries like Korea and the Philippines, its interference in Hong Kong affairs and its disrespect for the 
political choices of Taiwan's citizens. Its new leadership has also been manifest in initiatives like the AIIB and the BRI.

The new assertive China is most evident in its posture vis-à-vis the US. Chinese President $\mathrm{Xi}$ has been overtly trying to push the US out of East Asia and position China as the region's paramount power. In arguing for "a new security cooperation architecture", Xi quite pointedly expressed his view on the role of the US in Asia when he said that "strengthening military alliances with a third party does not benefit the maintenance of regional security ... it is for the people of Asia to run the affairs of Asia, solve the problems of Asia and uphold the security of Asia. The people of Asia have the capability and wisdom to achieve peace and stability in the region through enhanced cooperation." 26

These developments have led some analysts to argue that the great power struggle between the US and China is pushing them to war. As Graham Allison has recalled, more than 2400 years ago, the Athenian historian Thucydides offered a powerful insight: "It was the rise of Athens, and the fear that this inspired in Sparta, that made war inevitable." 27 According to Allison, when a rising power rivals a ruling power, like Athens and Sparta, and Germany and Britain a century ago, the contests often end badly. Indeed, in 12 of 16 cases over the past 500 years, the result was war. "When the parties avoided war, it required huge, painful adjustments in attitudes and actions on the part not just of the challenger but also the challenged," wrote Allison.

Quite predictably, there has been much debate about the prospects for war between China and the US. Some argue that the dense trade, investment, finance and people-to-people relations between the two countries mean that war between the two countries would be too costly for both sides. But similarly close relations did not stop Germany and Britain from going to war a century ago. Another line of argument is that today China is so militarily inferior to the US. But if China's Communist Party were faced with an existential threat, such as over Taiwan or in the future even the South China Sea, it may fight for its life. And looking ahead, the balance of power between the Chinese and American militaries will narrow quickly over the coming decades, and the US military will likely remain more thinly spread across the globe, while China's remains more concentrated in East Asia.

Would China and the US be willing to make the huge, painful adjustments in attitudes and actions in order to avoid war? For his part, Chinese President Xi Jinping seemed rather stubborn when he argued "There is no 
such thing as the so-called Thucydides Trap in the world. But should major countries time and again make the mistakes of strategic miscalculation, they might create such traps for themselves. ${ }^{28}$ "

There are however reasons to believe that the possibility of traditional military war between the US and China is highly unlikely. Both sides are well aware that there would be no winners. Indeed, the potential for mutually assured destruction between two nuclear powers virtually rules out a full-blown military war.

The progressive fading of the US' influence in Asia could also reduce the possibility of conflict between China and the US. Over time, issues like the South China Sea and even Japan's Senkaku Islands could seem less and less important. They are, after all, just bunches of rocks, reefs, shoals and islets in seas which are an awfully long way from Washington.

Against that, there is always the risk of accidental conflicts spiraling out of control. Several naval accidents involving the US Navy in 2017, which fortunately did not involve Chinese ships, highlight how easily accidents can occur in Asia's highly congested shipping lanes. And possible economic stagnation could see the Chinese government promote nationalism more aggressively, and resort to military adventurism as a diversionary tactic.

All things considered, the US and China seem destined to remain "frenemies", that is, both friends and rivals. In addition to the dense trade, investment, finance and people-to-people relations that bind the US and China together, the US needs China's cooperation on issues like North Korea, counter-terrorism, cyber-security, Iran and, depending on the administration, climate change. But as in recent times, rather than traditional military conflicts, we should expect conflicts in the areas of trade, intellectual property, international rule of law and cyber to be constantly bubbling, with even greater explosions from time to time. The likely inability to put an end to such conflicts will undermine the prospects for an Asian Century.

As China progressively displaces the US as Asia's hegemon, it will become ever more necessary for Asian countries to cooperate better together. The US has operated like a boxing referee who holds old enemies apart. However, as we have discussed in this chapter, Asia is bristling with tensions involving China on the one hand, and Japan, Taiwan, Hong Kong, North Korea, the South China Sea, ASEAN and India. And Chinese initiatives like the AIIB and the BRI are not seen with a friendly eye by all regional players. 
The most likely source of conflict in Asia could be between China and India or Japan, two countries that are unlikely to buckle under China's ambitious regional designs. Indeed, while Asian Century hype has focused substantially on the rise of China, India's population will surpass China's as early as 2022, and could be some $50 \%$ higher than China's by 2100 . And if current trends continue, India's economic size could overtake China's sometime in the second half of this century. Such a power shift could foster political instability in Asia, especially since India has more friends in Asia than does China.

Avoiding conflict for Japan may ultimately require political reconciliation with former adversaries. This is no easy task as the Chinese and Korean governments have invested so much in anti-Japanese nationalism, rather than looking to the future and fostering reconciliation.

Possible conflicts between Asian countries could do much to derail the prospects for an Asian Century. And the great risk for the US is being dragged into these conflicts between Asian countries, more than a straight head-on conflict with China.

\section{Notes}

1. Henry Kissinger on China, Nixon and OBL CBS NEWS, 4 June 2012.

2. Cha, Victor Cha (2016). Powerplay: The Origins of the American Alliance System in Asia.

3. Buchanan, Ian. Is regional economic integration enough? The search for "Wave 3" growth. Asia Pathways, 11 December 2012.

4. Barack Obama. Statement by the President on the 70th Anniversary Commemorating the End of World War II in the Pacific. The White House, 2 September 2015.

5. ABC. Prime Minister Tony Abbott holds first formal meeting with Japanese PM Shinzo Abe, 10 October 2013.

6. Nixon, Richard M. Asia After Viet Nam. Foreign Affairs, October 1967.

7. President Bill Clinton. Speech on China Trade Bill, 8 March 2000.

8. Office of the US Trade Representative.

9. Rhodium Group. China Investment Monitor.

10. Pei, Minxin. Everything You Think You Know About China Is Wrong. Foreign Policy, 29 August 2012.

11. Lowy Institute. Conference by Professor Akiko Fukushima of Aoyama Gakuin University and the Tokyo Foundation on 7 February 2017.

12. Full text of President Xi Jinping's speech on "one country, two systems" and how China rules Hong Kong. South China Morning Post, I July 2017. 
13. Khoo, Nicholas. Why ASEAN is in Disarray in the South China Sea. The National Interest, 7 October 2016.

14. West, John. Race to finance Asia's infrastructure heats up. FDI Intelligence, 10 May 2017.

15. Jinchen, Tian. "One Belt and One Road": Connecting China and the world. McKinsey\&Company, July 2016.

16. Asian Development Bank Annual Meeting, Frankfurt 2016. City of Sustainability. The Chinese One Belt One Road Initiative: Asian Perceptions.

17. Fitch Ratings. China's One Belt, One Road Initiative Brings Risks, 25 January 2017.

18. Arase, David. China's two Silk Roads: implications for Southeast Asia. Institute of Southeast Asian Studies, 22 January 2015.

19. Financial Times. Chinese investment adds to Sri Lankan debt pile, 24 February 2017.

20. Gunasekara, Shiyana. Sri Lanka Suffers from China's Indian Ocean Strategy. Asia Pacific Bulletin, 21 February 2017. East-West Center.

21. Asia-Pacific Banking and Finance. "Keating's China bank plans 'economic colonisation'," 27 February 2017.

22. IMF. Pakistan. Twelfth and Final Review under the extended arrangement, request for waivers or nonobservance of performance criteria, and proposal for post-program monitoring, 13 September 2016.

23. Asian Development Bank Annual Meeting, Frankfurt 2016. City of Sustainability. The Chinese One Belt One Road Initiative: Asian Perceptions.

24. Bremmer, Ian. Singapore PM Lee Hsien Loong on America's Declining Influence in Asia. Time Magazine, 26 October 2016.

25. Allison, Graham and Robert Blackwill. Interview: Lee Kuan Yew on the Future of U.S.-China Relations. The Atlantic, 5 March 2013.

26. Xi Jinping. New Asian security concept for new progress in security cooperation. Remarks at the Fourth Summit of the Conference on Interaction and Confidence Building Measures in Asia, 21 May 2014.

27. Allison, Graham. The Thucydides Trap: Are the U.S. and China Headed for War? The Atlantic, 24 September 2015.

28. Xi Jinping, Speech on China-U.S. Relations, Seattle, 25 September 2015. 
Open Access This chapter is licensed under the terms of the Creative Commons Attribution 4.0 International License (http://creativecommons.org/licenses/ by $/ 4.0 /$ ), which permits use, sharing, adaptation, distribution, and reproduction in any medium or format, as long as you give appropriate credit to the original author(s) and the source, provide a link to the Creative Commons license and indicate if changes were made.

The images or other third party material in this chapter are included in the chapter's Creative Commons license, unless indicated otherwise in a credit line to the material. If material is not included in the chapter's Creative Commons license and your intended use is not permitted by statutory regulation or exceeds the permitted use, you will need to obtain permission directly from the copyright holder. 